\title{
Study on Low Temperature Oxidation Characteristics of Oil Shale Based on Temperature Programmed System
}

\author{
Wenzhou Du ${ }^{1,2}$, Yue Wang ${ }^{2, *(D)}$, Xuelin Liu ${ }^{2}$ and Lulu Sun ${ }^{1,2}$ \\ 1 Mine Disaster Prevention and Control-Ministry of State Key Laboratory Breeding \\ Base, Shandong University of Science and Technology, Qingdao 266590, China; \\ duwenzhou-01@163.com (W.D.); sunsdust@126.com (L.S.) \\ 2 College of Mining and Safety Engineering, Shandong University of Science and Technology, \\ Qingdao 266590, China; gang.wang@sdust.edu.cn \\ * Correspondence: sdkdwangyue@163.com; Tel.: +86-131-5636-9956
}

Received: 9 September 2018; Accepted: 27 September 2018; Published: 29 September 2018

\begin{abstract}
Oil shale is a kind of high-combustion heat mineral, and its oxidation in mining and storage are worth studying. To investigate the low-temperature oxidation characteristics of oil shale, the temperature, $\mathrm{CO}$, alkane and alkene gases were analyzed using a temperature-programmed device. The results showed that the temperature of oil shale underwent three oxidation stages, namely a slow low-temperature oxidation stage, a rapid temperature-increasing oxidation stage, and a steady temperature-increasing stage. The higher the air supply rate is, the higher the crossing point temperature is. Similar to coal, $\mathrm{CO}$ also underwent three stages, namely a slow low-temperature oxidation stage, a rapid oxidation stage, and a steady increase stage. However, unlike coal, alkane and alkene gases produced by oil shale underwent four stages. They all had a concentration reduction stage with the maximum drop of $24.20 \%$. Statistical classification of inflection temperature of various gases as their concentrations change showed that the temperature of $140{ }^{\circ} \mathrm{C}$ is the key temperature for group reactions, and above the temperature of $140{ }^{\circ} \mathrm{C}$, all alkane and alkene gases underwent the rapid concentration increase stage.
\end{abstract}

Keywords: oil shale; low temperature oxidation; temperature-programmed experiment; temperature; gas

\section{Introduction}

The wide application of fossil fuels provides sufficient energy support for industrial production. Oil shale is a combustible, fine bedding sedimentary rock consisting of inorganic minerals and $15-50 \%$ organic matters including organic polymers [1]. The latter is mainly kerogen and distributed in the framework of minerals. The proven oil shale reserves in the world exceed 400 billion tons. As an alternative resource for petroleum, it has been widely exploited around the world [2,3]. Kerogen in oil shale is mainly composed of carbon, hydrogen, and oxygen and can directly react with oxygen [4]. When oil shale is heated to about $500{ }^{\circ} \mathrm{C}$, its kerogen undergoes pyrolysis and produces petroleum-like shale oil, which can be further processed to extract gasoline, kerosene, diesel and other liquid fuels [5]. During the pyrolysis of oil shale, pyrolysis gases or retort gases are produced including $\mathrm{CO}, \mathrm{CO}_{2}, \mathrm{CH}_{4}$, and $\mathrm{C}_{\mathrm{n}} \mathrm{H}_{\mathrm{m}}$ (hydrocarbons with the number of $\mathrm{C} \leq 4$ except $\mathrm{CH}_{4}$ ) [6]. Studying the compositions of gases generated from the heated oil shale is of great significance for industrial production. It is well known that oil shale, as an underground combustible, high-ash sedimentary mineral, has tendency for spontaneous combustion during excavation. For example, five-oil shale spontaneous combustion accidents, along with toxic and harmful gas intrusions, occurred at the 6112 oil shale working face of 
Haishiwan Coal Mine in 2012 [7]. Index gases are a series of gases that are generated in the oxidation process. From the oxidation index gas, it is easy to judge the oxidation stage of coal, oil shale and other materials. Therefore, studying the changes in index gases and temperature of oil shale during low temperature oxidation is of great significance for the safe and efficient oil shale excavation.

Researchers have in-depth studied the characteristics of temperature rise and gas production of oil shale based on the pyrolysis temperature, temperature increase rate, retention period, pyrolysis atmosphere, operating pressure, particle size and density, as well as inorganic content [8-12]. Ots analyzed the formation of nitrogen oxides, sulfur oxides, polycyclic aromatic hydrocarbons and ash in oil shale direct-combustion process [13]. Tariksaif determined the fracture numbers and mineral contents of oil shale before and after pyrolysis of oil shale using X-ray micro-computed tomography (X-ray $\mu \mathrm{CT}$ ), automated ultra-high resolution scanning electron microscopy (SEM), Modular Automated Processing System (MAPS), and Focused Ion Beam Scanning Electron Microscopy (FIB-SEM) [14]. Konist et al. studied the effects of supply gas with different $\mathrm{N}_{2}, \mathrm{O}_{2}$ and $\mathrm{CO}_{2}$ ratios on C-bearing groups decomposition and $\mathrm{SO}_{2}$ production of oil shale at 800,850 and $900{ }^{\circ} \mathrm{C}$ and found that the $\mathrm{CO}_{2}$ content in supply gas has the greatest impact [15]. Jiang et al. determined the optimal pyrolysis temperature of Huadian oil shale and evaluated the catalytic properties of transition metal salts on oil shale [16]. Wang found that increase in temperature rise rate could accelerate the heat transfer rate and improve the pyrolysis rate of organic materials, which are inductive to pyrolysis product extraction. In addition, the increase in particle size can enlarge the escape route of pyrolysis products, promote secondary cracking reaction, and reduce the content of shale oil [17]. Aboulkas and El Harfi analyzed kerogen in oil shale using TG/DTG and found that increasing the heating rate could shift the maximum rate loss to a higher temperature [18].

Pyrolysis is usually used to study the oxidation of oxides at temperatures above $500{ }^{\circ} \mathrm{C}$. However, the oxidation of oil shale in a natural state occurs at low temperature oxidation from room temperature up to $200{ }^{\circ} \mathrm{C}$. Therefore, researchers usually examine the oxidation characteristics of materials at low temperature using a temperature-programmed method, which refers to the method of heating materials at a certain rate in the external environment while supplying air or proposed gas components to analyze changes in the temperature, gas generation rate, oxygen consumption rate, and other related physical parameters in the heating process. The crossing point temperature between the mineral and temperature-programmed tank is an important parameter for judging the oxidative capability of the material. Generally speaking, above the crossing point temperature, coal rock enters the rapid oxidation stage, and its temperature begins to rise rapidly. Therefore, in actual excavation, this temperature is used as an important indicator for judging the oxidation of residual coal in the goaf $[19,20]$. The indicative gas is another important investigated index. In general, $\mathrm{CO}, \mathrm{CO}_{2}$, and other alkane and alkene gases will be produced during coal oxidation and temperature rise. Thus, studying the temperature at which certain gas is produced and its variation is of importance for understanding the oxidation performance of the coal rock [21-24] and developing fire prevention and extinguishment schemes based on temperature rise features for safe production in coal mines $[25,26]$.

Su et al. used a temperature-programmed tank to study the coal's oxidation states at different oxygen supply rates and quantitatively analyzed the effect of gas concentration on its oxidation risk [27]. Tang studied the oxidation of oil shale in the range of $60-150{ }^{\circ} \mathrm{C}$ through a temperature-programmed device and analyzed oxygen consumption rates and gas products, and found that both $\mathrm{C}_{2} \mathrm{H}_{4}$ and $\mathrm{H}_{2}$ cannot be used as representative gases to predict spontaneous combustion of oil shale in the underground oil shale mines [28]. Qi et al. used a temperature-programmed experimental device to accurately test the amount of heat produced by oxidation of coal in different oxygen concentration atmospheres, based on which the kinetic parameters (the activation energy and the pre-exponential factors) of low-temperature oxidation in coal can be worked out [29]. Wang et al. utilized a temperature-programmed device to study $\mathrm{CO}$ and $\mathrm{CO}_{2}$ production rates during coal decomposition at $60-110{ }^{\circ} \mathrm{C}$ and found that $\mathrm{CO}$ and $\mathrm{CO}_{2}$ production rates are temperature-dependent, but independent of the particle size of the samples, indicating that the thermal decomposition process 
is dominated by chemical kinetics rather than diffusion [30]. Li et al. conducted isothermal oxidation experiments on raw-coal and pyrolytic samples using a temperature-programmed device to study the effects of oxygen-containing functional group content, pyrolysis temperature, oxidation temperature, particle size, pyrolysis and pyrolysis times on the oxidation properties of coal samples [31]. Wang et al. used a temperature-programmed experimental setup to determine the impact of secondary oxidation on residual coal in the goaf [32].

The pyrolysis and combustion of oil shale under high temperature conditions have been extensively explored. However, the characteristics of released heat and light gas extraction of oil shale in low temperature oxidation process have not been deep studied. In this study, we examined the characteristics of temperature change and extracted gases of oil shale from Liangiia Coal Mine, China, during low-temperature oxidation in temperature-programmed experiments. It will provide the theoretical foundation for studies on oil shale in low-temperature oxidation, and determination of operation parameters in retorting process and design of the retort furnace. The results of these tests will be a comparison of the results obtained with the provision of information on what constitutes the main obstacles to an effective process of obtaining useful minerals and also have a great significance on environmental pollution control caused by oil shale combustion.

\section{Materials and Methods}

\subsection{Preparation of Oil Shale Samples}

Liangjia Coal Mine is located in Shandong Province, China. Although it mainly mines coals, there is some co-mining face of coal and oil shale at some mining areas. In the present study, the 1105 coal and oil shale co-mining faces were selected as the research target. The selected fresh oil shale samples were placed on sealed bags. During the preparation of experimental samples, the following procedures were taken: (1) peeling off the oxidized layers of the raw oil shale samples; (2) rapidly processing the samples to a particle size range of $0.18-0.38 \mathrm{~mm}$; and (3) rapidly drying the samples in a drying oven for future use.

\subsection{Temperature-Programmed Experimental Device and Experimental Process}

Figure 1 shows the temperature-programmed experimental device modified from a 2000-type coal spontaneous combustion tester. The device consists mainly of an air supply system (as shown in Figure 1a), a temperature-programmed reaction system (as shown in Figure 1b), as well as a temperature and gas concentration detection system (as shown in Figure 1c). The gas supply system uses a QPT-300G joint nitrogen-hydrogen-air generator to separately provide standard gases. Three control experiments with air supple rates of $30 \mathrm{~mL} / \mathrm{min}, 50 \mathrm{~mL} / \mathrm{min}$ and $70 \mathrm{~mL} / \mathrm{min}$ were designed. The experimental steps are listed as: (1) putting a 40 gam oil shale sample with a precise platinum-resistance temperature sensor embedded in the center of the reaction chamber; (2) injecting the air into the temperature-programmed reaction system; (3) heating the air at a heating rate of $0.5^{\circ} \mathrm{C} / \mathrm{min}$ with an accuracy of $0.1^{\circ} \mathrm{C}$; (4) injecting the hot air into the coal sample reaction tank to heat and oxidize the oil shale; (5) analyzing the concentration of hot air entering the gas chromatograph through the pipeline on the top of the sample tank, and (6) finishing the experiment and analyzing the experimental data. 


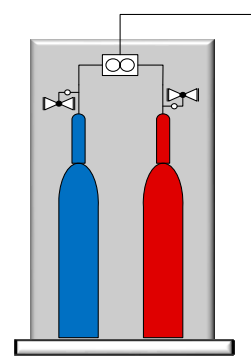

a

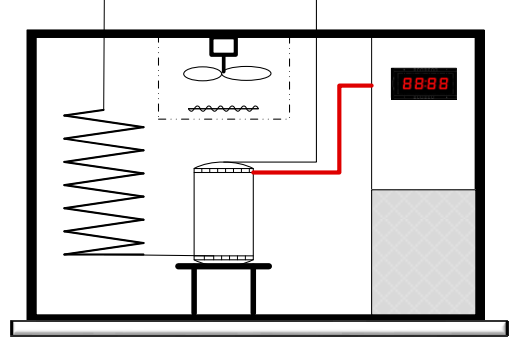

$\mathrm{b}$

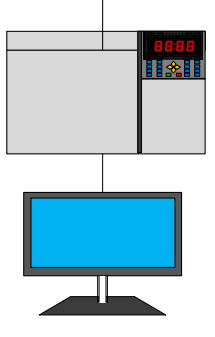

C

Figure 1. Temperature-programmed system: (a) air supply system; (b) temperature-programmed reaction system; (c) gas concentration detection system.

\section{Results}

Figure 2 shows the relationship between the oil shale temperature and time at different air supply rates. From Figure 2, it is clear that the oxidation and temperature increase process of oil shale mainly showed three stages: an initial slow oxidation stage followed in turn by a rapid temperature-increasing oxidation stage and a steady temperature-increasing oxidation stage. The air supply rate significantly affected the starting temperature of the rapid temperature-increasing oxidation stage. The greater the air supply rate is, the more sufficient the oxygen supply is and the earlier the oil shale enters the rapid temperature-increasing oxidation stage. In the rapid temperature-increasing oxidation stage, the crossing point temperatures were shown in all shale samples, which is a significant index of coal oxidation. The lower the crossing point temperature was, the stronger the capability of oil shale to be oxidized was. The crossing point temperatures of oil shale samples were $120^{\circ} \mathrm{C}, 123^{\circ} \mathrm{C}$ and $129^{\circ} \mathrm{C}$ at air supply rates of $70 \mathrm{~mL} / \mathrm{min}, 50 \mathrm{~mL} / \mathrm{min}$ and $30 \mathrm{~mL} / \mathrm{min}$, respectively. In the second oil shale oxidation stage, the greater the air supply rate is, the higher the oil shale temperature is. Above $150^{\circ} \mathrm{C}$, all three samples simultaneously entered the steady oxidation stage with roughly the same temperature increase rates. Temperature in the steady oxidation stage is positively correlated with the air supply rate.

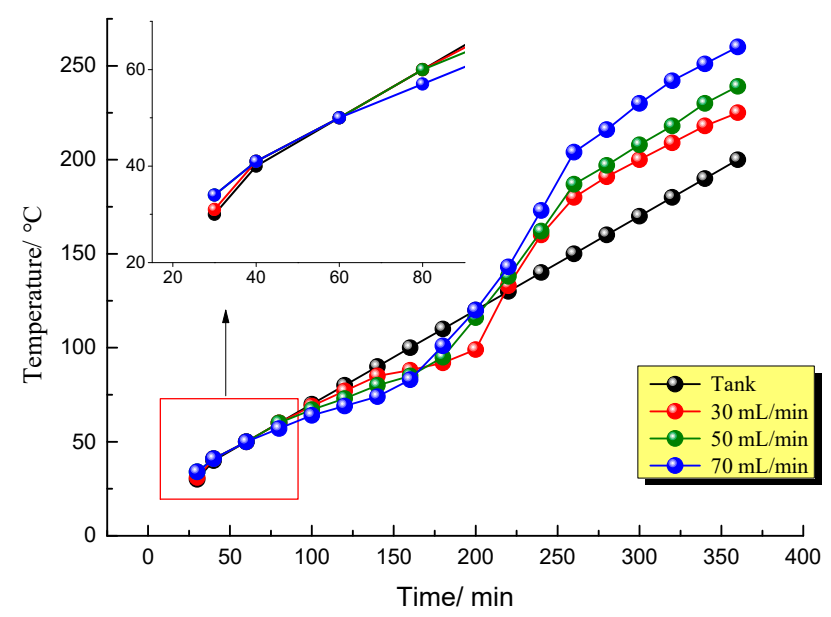

Figure 2. Relationship between the temperature and the time at different air supply rates.

$\mathrm{CO}$ is one of the main index gases produced in the low-temperature oxidation stage of carbonaceous materials. As shown in Figure 3, the CO concentration of oil shale sample showed a trend of a stable stage, a rapid growth and a slow growth stage. The higher the air supply rate, the lower the inflection temperature of stage transition. At temperature higher than $140{ }^{\circ} \mathrm{C}$, oil shale samples at the three different air supply rates simultaneously transited into a rapid $\mathrm{CO}$ generation stage, indicating that the air supply rate plays a positive role in $\mathrm{CO}$ production with a characteristic that the higher the air supply rate is, the more the $\mathrm{CO}$ production is. Oil shale samples entered the slow 
growth oxidation stage at inflection temperatures of $160^{\circ} \mathrm{C}, 170^{\circ} \mathrm{C}$ and $180^{\circ} \mathrm{C}$ at air supply rates of 70,50 and $30 \mathrm{~mL} / \mathrm{min}$, respectively, indicating that the temperature of oil shale into the slow oxidation stage is negatively correlated with air supply rate increasing. The final CO concentrations of the three samples from high to low corresponded to samples at air supply rates of $50 \mathrm{~mL} / \mathrm{min}, 70 \mathrm{~mL} / \mathrm{min}$, and $30 \mathrm{~mL} / \mathrm{min}$, and the growth rates of the three samples were approximately the same. The reason may be that: (1) sufficient oxygen supply at an air supply rate of $70 \mathrm{~mL} / \mathrm{min}$ could result in full oxidization of carbon inside the oil shale sample, resulting in a decreased $\mathrm{CO}$ production in the later stage; (2) oxygen supply at an air supply rate of $50 \mathrm{~mL} / \mathrm{min}$ was closer to its stoichiometric ratio, resulting in the highest $\mathrm{CO}$ concentration in the later stage; and (3) insufficient oxygen supply at an air supply rate of $30 \mathrm{~mL} / \mathrm{min}$ led to poor $\mathrm{C}$ oxidation, resulting in the lowest $\mathrm{CO}$ production and causing that the sample entered into the slow oxidation intersection at the highest temperature.

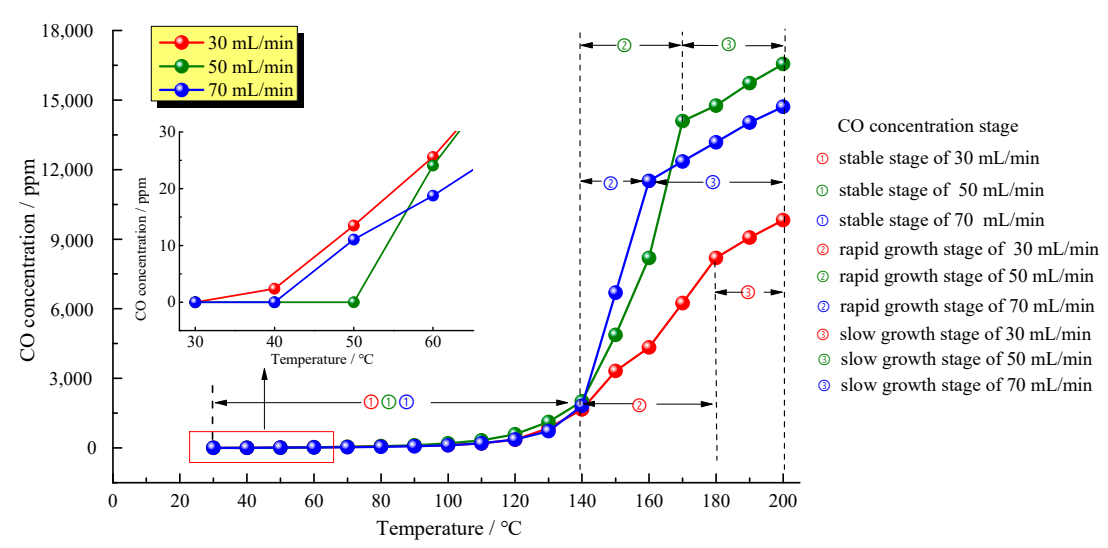

Figure 3. Relationship between the CO concentration and the temperature at different air supply rates.

Figure 4 shows the relationships between $\mathrm{CH}_{4}$ concentrations and temperatures at the three different air supply rates. It is clear that $\mathrm{CH}_{4}$ production during the low temperature oxidation of oil shale mainly underwent four stages. In the initial $\mathrm{CH}_{4}$ production stage, oil shale samples started to produce $\mathrm{CH}_{4}$ at $130{ }^{\circ} \mathrm{C}$ at air supply rates of 50 and $70 \mathrm{~mL} / \mathrm{min}$ and at $140{ }^{\circ} \mathrm{C}$ at an air supply rate of $30 \mathrm{~mL} / \mathrm{min}$, indicating that a high air supply rate helps produce $\mathrm{CH}_{4}$. As the temperature increased, oil shale samples entered a slow $\mathrm{CH}_{4}$ production stage named a stable stage in roughly the same temperature ranges, indicating that the air supply rate has no significant effect on the initial $\mathrm{CH}_{4}$ production. Above $140{ }^{\circ} \mathrm{C}$, three oil shale samples all synchronically entered a $\mathrm{CH}_{4}$ rapid growth stage. During the stage, oil shale samples fully reacted with oxygen, resulting in a rapid increase in the $\mathrm{CH}_{4}$ concentration with a characteristic that the faster the air supply rate, the higher the $\mathrm{CH}_{4}$ production rate. The rapid oxidation stage ended at $160^{\circ} \mathrm{C}$ with an air supply rate of $70 \mathrm{~mL} / \mathrm{min}$ and at $170{ }^{\circ} \mathrm{C}$ with an air supply rate of $50 \mathrm{~mL} / \mathrm{min}$ as $\mathrm{CH}_{4}$ concentration decreased. However, the decrease of $\mathrm{CH}_{4}$ concentration did not appear at the sample with an air supply rate of $30 \mathrm{~mL} / \mathrm{min}$ till the end of the experiment. It can be deduced that the rapid growth stage end-temperature of $30 \mathrm{~mL} / \mathrm{min}$ sample was more than $200^{\circ} \mathrm{C}$. At last, different from the $\mathrm{CH}_{4}$ production of coal in the low-temperature oxidation process, oil shale entered a $\mathrm{CH}_{4}$ concentration decrease stage after reaching a certain temperature, as the $\mathrm{CH}_{4}$ concentration reduced by $13.02 \%$ at an air supply rate of $50 \mathrm{~mL} / \mathrm{min}$ and by $9.65 \%$ at an air supply rate of $70 \mathrm{~mL} / \mathrm{min}$. Due to higher air supply rates and sufficient oxygen, this stage was shorter at an air supply rate of $70 \mathrm{~mL} / \mathrm{min}$. At temperatures higher than $170{ }^{\circ} \mathrm{C}$, oil shale samples started to produce $\mathrm{CH}_{4}$ at a slower rate. 


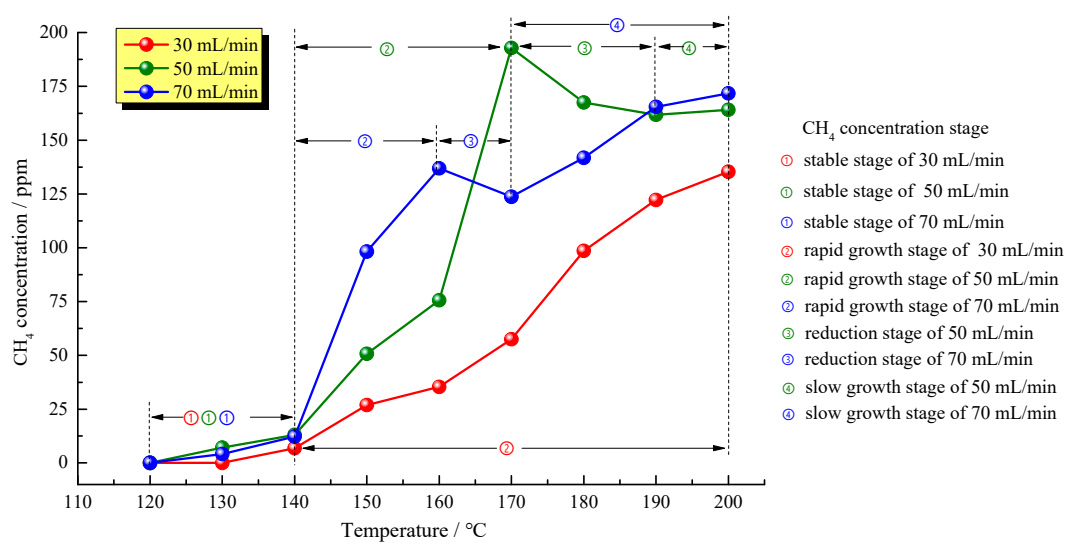

Figure 4. Relationship between the $\mathrm{CH} 4$ concentration and the temperature at different air supply rates.

Figure 5 shows changes in $\mathrm{C}_{2} \mathrm{H}_{6}$ concentrations with temperature at the three different air supply rates. It is clear from Figure 5 that, similar to $\mathrm{CH}_{4}$ production, the $\mathrm{C}_{2} \mathrm{H}_{6}$ production from oil shale in the low-temperature oxidation process also underwent four stages: an initial stable stage, followed in turn by a rapid growth stage, a concentration reduction stage, and a slow growth stage. The samples at air supply rates of $50 \mathrm{~mL} / \mathrm{min}$ and $70 \mathrm{~mL} / \mathrm{min}$ began to produce $\mathrm{C}_{2} \mathrm{H}_{6}$ at $110{ }^{\circ} \mathrm{C}$ at the same time and the sample at an air supply rate of $30 \mathrm{~mL} / \mathrm{min}$ began to produce $\mathrm{C}_{2} \mathrm{H}_{6}$ at $120^{\circ} \mathrm{C}$. With slow $\mathrm{C}_{2} \mathrm{H}_{6}$ concentration increase, at $140{ }^{\circ} \mathrm{C}$, all oil shale samples simultaneously entered the rapid $\mathrm{C}_{2} \mathrm{H}_{6}$ growth stage and showed characteristics that the greater the air supply rate, the faster the $\mathrm{C}_{2} \mathrm{H}_{6}$ production rate. Interestingly, higher air supply rate did not mean more $\mathrm{C}_{2} \mathrm{H}_{6}$ production. The concentration of $\mathrm{C}_{2} \mathrm{H}_{6}$ produced from oil shale at the highest air supply rate of $70 \mathrm{~mL} / \mathrm{min}$ began to decrease when temperature reached $160{ }^{\circ} \mathrm{C}$, and regained growth when the temperature reached $180{ }^{\circ} \mathrm{C}$. The concentration of $\mathrm{C}_{2} \mathrm{H}_{6}$ produced from oil shale at an air supply rate of $50 \mathrm{~mL} / \mathrm{min}$ began to decline at $180{ }^{\circ} \mathrm{C}$ at a slower rate. Therefore, the peak $\mathrm{C}_{2} \mathrm{H}_{6}$ amount produced from oil shale sample at an air supply rate of $50 \mathrm{~mL} / \mathrm{min}$ was greater than that from the oil shale sample at an air supply rate of $70 \mathrm{~mL} / \mathrm{min}$. In addition, the $\mathrm{C}_{2} \mathrm{H}_{6}$ concentration only decreased at a narrow temperature range of $180-190{ }^{\circ} \mathrm{C}$ at an air supply rate of $50 \mathrm{~mL} / \mathrm{min}$. At last, oil shale samples at air supply rates of 50 and $70 \mathrm{~mL} / \mathrm{min}$ entered in a slow $\mathrm{C}_{2} \mathrm{H}_{6}$ growth stage with similar $\mathrm{C}_{2} \mathrm{H}_{6}$ concentrations. Differently, the oil shale sample at an air supply rate of $30 \mathrm{~mL} / \mathrm{min}$ entered the rapid $\mathrm{C}_{2} \mathrm{H}_{6}$ growth stage at $140{ }^{\circ} \mathrm{C}$. By the end of the experiment when the temperature was higher than $200{ }^{\circ} \mathrm{C}$, the $\mathrm{C}_{2} \mathrm{H}_{6}$ concentration was still increasing but at growth rates of $37.59 \%$ and $23.23 \%$ corresponding to air supply rates of 50 and $70 \mathrm{~mL} / \mathrm{min}$, respectively. Presumably, the $\mathrm{C}_{2} \mathrm{H}_{6}$ reduction stage of $30 \mathrm{~mL} / \mathrm{min}$ oil shale sample was more than $200^{\circ} \mathrm{C}$.

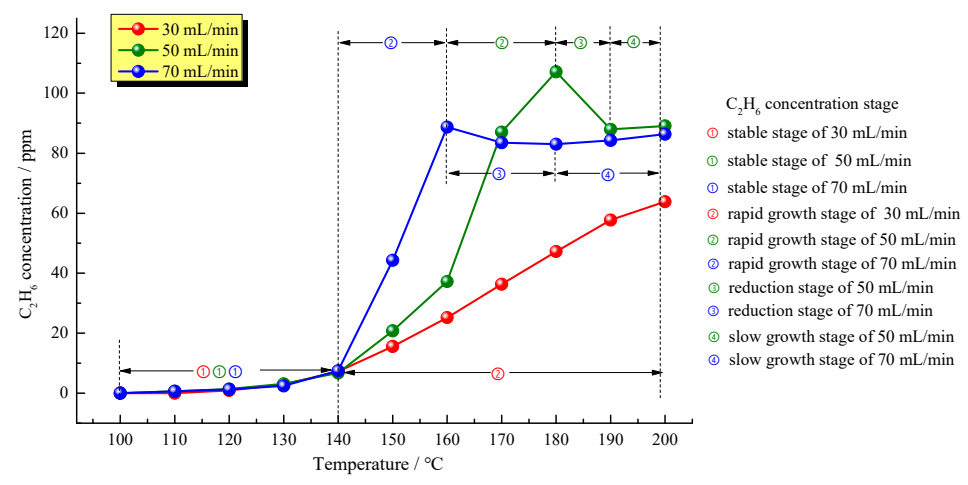

Figure 5. Relationship between the $\mathrm{C} 2 \mathrm{H} 6$ concentration and temperature at different air supply rates.

Figure 6 shows changes in $\mathrm{C}_{3} \mathrm{H}_{8}$ concentration with temperature at the three different air supply rates. It is clear from Figure 6 that, similar to $\mathrm{C}_{2} \mathrm{H}_{6}$ production, the propane production from oil 
shale in the low-temperature oxidation process also underwent four stages. However, unlike $\mathrm{C}_{2} \mathrm{H}_{6}$, the air supply rates of $30 \mathrm{~mL} / \mathrm{min}$ and $50 \mathrm{~mL} / \mathrm{min}$ were generated at $130^{\circ} \mathrm{C}$ and the oil shale sample at an air supply rate of $70 \mathrm{~mL} / \mathrm{min}$ did not generated $\mathrm{C}_{3} \mathrm{H}_{8}$ until the temperature reached $140{ }^{\circ} \mathrm{C}$, revealing that air supply rate plays a negative role in $\mathrm{C}_{3} \mathrm{H}_{8}$ production of oil shale. At $130-140{ }^{\circ} \mathrm{C}$, all oil shale samples were in the stable stages, which had a slow oxidation and where the $\mathrm{C}_{3} \mathrm{H}_{8}$ production was slow. Above $140{ }^{\circ} \mathrm{C}$, all oil shale samples simultaneously stepped into the rapid $\mathrm{C}_{3} \mathrm{H}_{8}$ growth stage. $\mathrm{C}_{3} \mathrm{H}_{8}$ production started to decrease at $160{ }^{\circ} \mathrm{C}$ and $170{ }^{\circ} \mathrm{C}$ for oil shale samples at air supply rates of $70 \mathrm{~mL} / \mathrm{min}$ and $50 \mathrm{~mL} / \mathrm{min}$, respectively, similar to the case in $\mathrm{C}_{2} \mathrm{H}_{6}$ production. Nevertheless, different from the $\mathrm{C}_{2} \mathrm{H}_{6}$ production, the air supply rate has a positive effect on the peak $\mathrm{C}_{3} \mathrm{H}_{8}$ concentration: the peak $\mathrm{C}_{3} \mathrm{H}_{8}$ concentration was $68.51 \mathrm{ppm}$ at $150{ }^{\circ} \mathrm{C}$ for oil shale at an air supply rate of $70 \mathrm{~mL} / \mathrm{min}$ and $63.71 \mathrm{ppm}$ at $150{ }^{\circ} \mathrm{C}$ for oil shale at an air supply rate of $50 \mathrm{~mL} / \mathrm{min}$. Due to slow oxidation of oil shale at an air supply rate of $30 \mathrm{~mL} / \mathrm{min}, \mathrm{C}_{3} \mathrm{H}_{8}$ concentration did not reach its peak by the end of the experiment, with a maximum of $39.52 \mathrm{ppm}$. After reaching the peak concentrations, $\mathrm{C}_{3} \mathrm{H}_{8}$ concentration of oil shale reduced from $68.51 \mathrm{ppm}$ to $64.31 \mathrm{ppm}$ at an air supply rate of $70 \mathrm{~mL} / \mathrm{min}$ by $6.13 \%$, and decreased from $63.71 \mathrm{ppm}$ to $63.59 \mathrm{ppm}$ at an air supply rate of $50 \mathrm{~mL} / \mathrm{min}$ by $0.19 \%$. Afterwards, $\mathrm{C}_{3} \mathrm{H}_{8}$ concentrations of both samples began to gradually rise when the temperature exceeded $180^{\circ} \mathrm{C}$. As a whole, the higher the air supply rate, the more $\mathrm{C}_{3} \mathrm{H}_{8}$ generated eventually.

Figure 7 shows changes in $\mathrm{C}_{2} \mathrm{H}_{4}$ concentrations of oil shale with temperature at the three different air supply rates. As a key index gas used for judging the oxidation state of residual coal, $\mathrm{C}_{2} \mathrm{H}_{4}$ was specifically studied in the temperature-programmed experiment. It is clear from Figure 7 that $\mathrm{C}_{2} \mathrm{H}_{4}$ was not produced from oil shale in the low-temperature oxidation process when temperature was lower than $120{ }^{\circ} \mathrm{C}$. At $120{ }^{\circ} \mathrm{C}$, the concentrations of $\mathrm{C}_{2} \mathrm{H}_{4}$ produced from oil shale samples at air supply rates of 50,70 and $30 \mathrm{~mL} / \mathrm{min}$ were $1.16 \mathrm{ppm}, 1.16 \mathrm{ppm}$, and $0.7 \mathrm{ppm}$, respectively. With temperature increasing, $\mathrm{C}_{2} \mathrm{H}_{4}$ concentrations of the three samples increased slowly before the temperature reached $140^{\circ} \mathrm{C}$, showing no significant increase and the same concentration basically. These results indicated that, in the initial oxidation stage, the air supply rate has no significant effect on the production of $\mathrm{C}_{2} \mathrm{H}_{4}$. Above $140{ }^{\circ} \mathrm{C}$, oil shale at an air supply rate of $70 \mathrm{~mL} / \mathrm{min}$ first stepped into the rapid $\mathrm{C}_{2} \mathrm{H}_{4}$ growth stage with a $\mathrm{C}_{2} \mathrm{H}_{4}$ increase rate of $1.18 \mathrm{ppm} /{ }^{\circ} \mathrm{C}$ and this increase stopped at $160{ }^{\circ} \mathrm{C}$; similarly, oil shale at an air supply rate of $50 \mathrm{~mL} / \mathrm{min}$ entered the rapid $\mathrm{C}_{2} \mathrm{H}_{4}$ growth stage with a $\mathrm{C}_{2} \mathrm{H}_{4}$ increase rate of $0.69 \mathrm{ppm} /{ }^{\circ} \mathrm{C}$ and the growth stopped at $170{ }^{\circ} \mathrm{C}$. After the end of the rapid growth stage, oil shale samples at air supply rates of 50 and $70 \mathrm{~mL} / \mathrm{min}$ entered the $\mathrm{C}_{2} \mathrm{H}_{4}$ concentration reduction stage at $160-180{ }^{\circ} \mathrm{C}$ and $170-180{ }^{\circ} \mathrm{C}$, with $\mathrm{C}_{2} \mathrm{H}_{4}$ concentrations reducing by $24.20 \%$ and $5.53 \%$, respectively. Afterwards, oil shale samples at air supply rates of 50 and $70 \mathrm{~mL} / \mathrm{min}$ stepped again into the slow growth stage with the $\mathrm{C}_{2} \mathrm{H}_{4}$ concentration fluctuating between $16.83 \mathrm{ppm}$ and $29.22 \mathrm{ppm}$ eventually. Oil shale at an air supply rate of $30 \mathrm{~mL} / \mathrm{min}$ entered the rapid $\mathrm{C}_{2} \mathrm{H}_{4}$ growth stage till the end of the experiment with a $\mathrm{C}_{2} \mathrm{H}_{4}$ increase rate of $0.22 \mathrm{ppm} /{ }^{\circ} \mathrm{C}$. However, due to the slower air supply rate, the $\mathrm{C}_{2} \mathrm{H}_{4}$ concentration reached maximum of $18.22 \mathrm{ppm}$ by the end of the experiment without undergoing the reduction stage. 


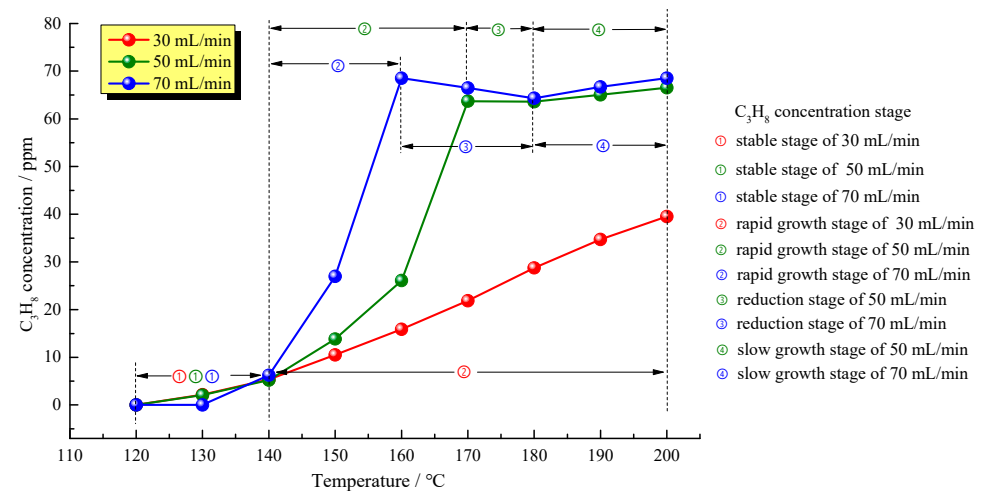

Figure 6. Relationship between the $\mathrm{C}_{3} \mathrm{H}_{8}$ concentration and the temperature at different air supply rates.

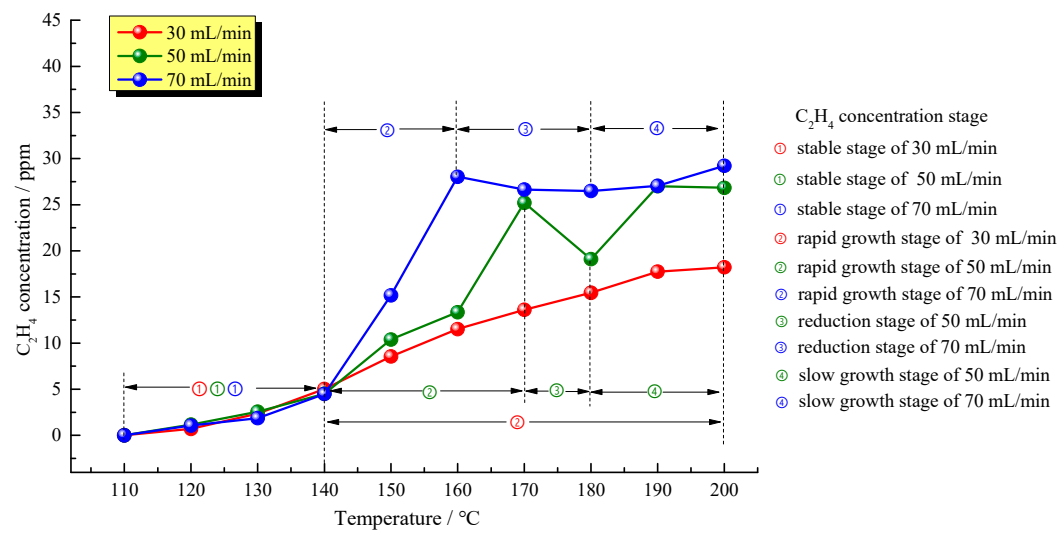

Figure 7. Relationship between the $\mathrm{C} 2 \mathrm{H} 4$ concentration and the temperature at different air supply rates.

\section{Discussion}

In the present study, we analyzed the oxidation stages of oil shale at different air supply rates in the low-temperature oxidation process by examining changes in concentrations of gases produced from oil shale samples with temperature using a temperature-programmed experimental device.

At the initial stage of programmed temperature, the temperature of oil shale samples dropped, similar to that of coal, indicating that the oil shale samples were in the latent oxidation period. The higher the air supply rate, the lower the oil shale temperature. After $100 \mathrm{~min}$, temperatures of oil shale samples rapidly increased and were positively correlated with the air supply rate. The higher the air supply rate was, the earlier the rapid increasing temperature began and the greater the temperature-increasing rate and range were. The air supply rate had a positive effect on the crossing point temperature, revealing that the higher the air supply rate, the lower the crossing point temperature. However, the air supply rate had no effect on the ends of rapid temperature increasing stage, and after that, three samples kept the same temperature-increasing rate. Therefore, the variation in oil shale temperature rise clearly showed that oil shale in the low temperature oxidation process had three major stages, namely the initial slow oxidation stage, the rapid temperature-increasing oxidation stage and the steady temperature-increasing oxidation stage. The initial slow oxidation stage was mainly characterized as the continuous endothermic process, while the rapid temperature-increasing oxidation stage was mainly characterized as the greater temperature-increasing rate than the programmed temperature-increasing rate, appearance of crossing point temperature as well as massive-heat relief. In the steady temperature-increasing oxidation stage, the heating rates were roughly consistent with set values and no significant energy was released. 
The concentration and generation temperature of gases produced from oil shale in its temperature-programmed process were analyzed. Because oil shale contains a large amount of kerogens, we mainly studied gases produced by oxidation of $\mathrm{C}$ and $\mathrm{H}$ including $\mathrm{CO}, \mathrm{CH}_{4}, \mathrm{C}_{2} \mathrm{H}_{6}, \mathrm{C}_{3} \mathrm{H}_{8}$ and $\mathrm{C}_{2} \mathrm{H}_{4}$, and found the following results. The summary gas concentration stage is shown in Table 1 .

Table 1. Oil shale low-temperature oxidation and gas production stage.

\begin{tabular}{|c|c|c|c|c|c|}
\hline \multirow{2}{*}{ Gas } & \multirow{2}{*}{$\begin{array}{l}\text { Air Supply } \\
\text { Rate }\end{array}$} & \multicolumn{4}{|c|}{ Temperature Range $/{ }^{\circ} \mathrm{C}$} \\
\hline & & Stable Stage & $\begin{array}{l}\text { Rapid Growth } \\
\text { Stage }\end{array}$ & $\begin{array}{l}\text { Reduction } \\
\text { Stage }\end{array}$ & $\begin{array}{c}\text { Slow Growth } \\
\text { Stage }\end{array}$ \\
\hline \multirow{3}{*}{$\mathrm{CO}$} & 30 & $30-140$ & $140-180$ & $\mathrm{~N} / \mathrm{A}$ & $180-200$ \\
\hline & 50 & 50-140 & $140-170$ & $\mathrm{~N} / \mathrm{A}$ & $170-200$ \\
\hline & 70 & $40-140$ & $140-160$ & $\mathrm{~N} / \mathrm{A}$ & $160-200$ \\
\hline \multirow{3}{*}{$\mathrm{CH}_{4}$} & 30 & $130-140$ & $140-200$ & $\mathrm{~N} / \mathrm{A}$ & $\mathrm{N} / \mathrm{A}$ \\
\hline & 50 & $120-140$ & $140-170$ & $170-190$ & $190-200$ \\
\hline & 70 & $120-140$ & $140-160$ & $160-170$ & $\mathrm{~N} / \mathrm{A}$ \\
\hline \multirow{3}{*}{$\mathrm{C}_{2} \mathrm{H}_{6}$} & 30 & $110-140$ & $140-200$ & $\mathrm{~N} / \mathrm{A}$ & $\mathrm{N} / \mathrm{A}$ \\
\hline & 50 & $100-140$ & $140-180$ & $180-190$ & $190-200$ \\
\hline & 70 & $100-140$ & $140-160$ & $160-180$ & $180-200$ \\
\hline \multirow{3}{*}{$\mathrm{C}_{3} \mathrm{H}_{8}$} & 30 & $120-140$ & $140-200$ & $\mathrm{~N} / \mathrm{A}$ & $\mathrm{N} / \mathrm{A}$ \\
\hline & 50 & $130-140$ & $140-170$ & $170-180$ & $180-200$ \\
\hline & 70 & $130-140$ & $140-160$ & $160-180$ & $180-200$ \\
\hline \multirow{3}{*}{$\mathrm{C}_{2} \mathrm{H}_{4}$} & 30 & $110-140$ & $140-200$ & $\mathrm{~N} / \mathrm{A}$ & $\mathrm{N} / \mathrm{A}$ \\
\hline & 50 & $110-140$ & $140-170$ & $170-180$ & $180-200$ \\
\hline & 70 & $110-140$ & $140-160$ & $160-180$ & $180-200$ \\
\hline
\end{tabular}

$\mathrm{CO}$ is the most important oxidation resultant of $\mathrm{C}$ in oil shale kerogens. Oxidation of $\mathrm{C}$ was mainly divided into three stages. At temperature higher than $140{ }^{\circ} \mathrm{C}$, oil shale was in the slow oxidation stage, in which the air supply rate had no effect on the oxidation of $C$ and $C O$ production is limited. Above $140{ }^{\circ} \mathrm{C}$, oil shale samples simultaneously underwent a rapid $\mathrm{C}$ oxidation stage and air supply rate had a significant impact on the production of $\mathrm{CO}$. The higher the air supply rate, the faster the $\mathrm{CO}$ production rate and the sooner the rapid oxidation stage ended. However, the air supply rate was not completely positively correlated with CO production in oil shale samples. The oil shale sample gassed at an air supply rate of $50 \mathrm{~mL} / \mathrm{min}$ produced the largest amount of $\mathrm{CO}$. After entering the final low-temperature oxidation stage, all oil shale samples produced $\mathrm{CO}$ at roughly the same rate. Meanwhile, the temperature-increasing rate of oil shale samples was independent of temperature, and the $\mathrm{CO}$ generation rates for these three samples were approximately the same.

Alkane and alkene gases are the major products of $\mathrm{H}$ oxidation in kerogens of oil shale. Therefore, we analyzed the production of $\mathrm{CH}_{4}, \mathrm{C}_{2} \mathrm{H}_{6}, \mathrm{C}_{3} \mathrm{H}_{8}$ and $\mathrm{C}_{2} \mathrm{H}_{4}$ from oil shale samples and found that, similar to coal's temperature-programmed increase, oil shale did not produce these gases at temperature lower than $100{ }^{\circ} \mathrm{C}$. At temperatures of $100-140{ }^{\circ} \mathrm{C}$, three samples were in the stable stage and slowly produced these gases. At $140{ }^{\circ} \mathrm{C}$, all oil shale samples simultaneously stepped into the rapid growth stage, independent of the air supply rate. Tang placed oil shale samples at different constant temperature environments and found that, at $150{ }^{\circ} \mathrm{C}$, the concentrations of $\mathrm{C}_{2} \mathrm{H}_{4}$ and $\mathrm{CH}_{4}$ produced from oil shale were significantly higher than those produced at 125, 100, 80 and $60{ }^{\circ} \mathrm{C}$, consistent with our current findings [28]. Therefore, $140{ }^{\circ} \mathrm{C}$ is a critical temperature in the low temperature oxidation of oil shale. Above $140^{\circ} \mathrm{C}$, oil shale samples rapidly produced various alkane and alkene gases, with a characteristic that the higher the air supply rate, the faster the alkene gases-producing rate. The rapid growth stage of different gases produced from oil shale samples at different air supply rates ended at different time points. Interestingly, after the rapid growth stage, the concentrations of various alkene and alkene gases began to decrease, which was absent in the low-temperature oxidation process of coal. The largest gas concentration reduction dropped by up to 
$24.20 \%$ and then all gas concentrations increased again into a slow growth stage, which had a lower increasing rate than the rapid growth stage.

To further investigate the mechanism of alkene gases concentration reduction in oil shale oxidation, we analyzed kerogens group reaction in oil shale compared to coal. When coal samples encounter with oxygen, oxygen is physically adsorbed, releasing a small amount of heat and thereby raise the temperature. Meanwhile, chemical adsorption of oxygen leads to interaction of oxygen with the most active groups. In these oxidation reaction processes, these active structures will breakup and release free radicals, such as $-\mathrm{CH}_{2}-$ and $\mathrm{C}-\mathrm{O}$. These free radicals will simultaneously react with two types. The first type is producing gases including $\mathrm{H}_{2}, \mathrm{CH}_{4}, \mathrm{C}_{2} \mathrm{H}_{4}, \mathrm{C}_{2} \mathrm{H}_{2}, \mathrm{C}_{3} \mathrm{H}_{8}$, while the other type with oxygen is producing oxygen-containing gases, such as $\mathrm{CO}$ and $\mathrm{CO}_{2}$. At this time, a portion of oxygen atoms still react with the structures in coal rock, forming new and more oxygen-containing groups. Tang et al. analyzed the infrared spectra of both oil shale and coal samples and found that both of them have same chemical bond structures, revealing that the organic components of oil shale can also be oxidized at room temperature [28]. However, different from the coals, the contents of $-\mathrm{CH}_{2}-$ and $\mathrm{C}-\mathrm{O}$ in oil shale samples will decrease after an increase stage with temperature increasing. The temperature-programmed experimental results showed that, at temperature above $140{ }^{\circ} \mathrm{C}$, the concentrations of $\mathrm{CH}_{4}, \mathrm{C}_{2} \mathrm{H}_{6}, \mathrm{C}_{3} \mathrm{H}_{8}$ and $\mathrm{C}_{2} \mathrm{H}_{4}$ increased rapidly. It was found that the gas rapid growth stage is caused by the sufficient contents of $-\mathrm{CH}_{2}-$ and $\mathrm{C}-\mathrm{O}$, and the temperature of $140{ }^{\circ} \mathrm{C}$ is the critical triggering temperature for group reactions. Afterwards, the concentration of alkene gases decreased due to decrease of group concentration at the reduction stage. Because the coal sample tank was filled with air, the oil shale samples in the tank were oxidized and produced enough $-\mathrm{CH}_{2}-$ and $\mathrm{CO}$. Therefore, even if the $\mathrm{CO}$ concentration decreases, sufficient $\mathrm{O}_{2}$ and high temperature will oxidize more $\mathrm{C}$ to produce $\mathrm{CO}$, resulting in $\mathrm{CO}$ concentration increasing.

\section{Conclusions}

In the present study, we examined the released heat and the concentrations of generated gases from oil shale samples in the low temperature oxidation process using a temperature-programmed experiment with the set temperature-increasing rate of $0.5{ }^{\circ} \mathrm{C} / \mathrm{min}$ and air supply rates of 30,50 and $70 \mathrm{~mL} / \mathrm{min}$. The conclusions are as follows:

1. The released heat of oil shale samples subjected to different air supply rates showed three stages: the initial slow oxidation stage, the rapid temperature-increasing oxidation stage and the steady temperature-increasing oxidation stage. In the initial slow oxidation stage, oil shale mainly absorbs heat from the circumstance and enters the rapid oxidation stage as the temperature increases. The higher the air supply rate, the greater the heat dissipation and the lower the crossing point temperature.

2. The component of gases generated from the reaction of $\mathrm{C}$ and oxygen in the low temperature oxidation process of oil shale samples was analyzed. It was found that the $\mathrm{CO}$ production has three stages: the stable stage, rapid growth stage and the slow growth stage. The air supply rate has a positive effect on the $\mathrm{CO}$ production rate only in the rapid growth stage, but not on the subsequent slow growth stage.

3. Analyses of concentrations of some representative alkane and alkene gases during the low temperature oxidation of oil shale samples were performed. The oil shale samples in the low temperature oxidation stage undergoes the stable stage, rapid growth stage, reduction stage and slow growth stage. Unlike coals in programmed temperature-increasing process, oil shale had an extra concentration reduction stage, with the concentration dropped by up to $24.20 \%$.

4. All gases generated in the low-temperature oxidation process of oil shale had the same intersection temperature point of $140{ }^{\circ} \mathrm{C}$, at which oil shale samples at different air supply rates turned from the slow oxidation stage to the rapid growth stage. At temperatures above $140{ }^{\circ} \mathrm{C}$, the concentrations of various gases increased rapidly. By analyzing the reaction groups in 
the oil shale, it can be conclude that $140{ }^{\circ} \mathrm{C}$ is the key temperature for the reaction of various groups in the oil shale.

Author Contributions: Conceptualization, W.D. and Y.W.; data curation, X.L.; investigation, W.D. and Y.W.; resources, Y.W.; software, L.S.; supervision, W.D.; writing of the original draft, Y.W.; writing of review and editing, L.S.

Funding: This research was funded by National Natural Science Foundation of China (51704187), Natural Science Foundation of Shandong Province (ZR2017BEE054), Post-doctoral Innovation Project of Shandong Province 201703024 and Post-doctoral Application Research Project of Qingdao 2017-267.

Acknowledgments: This research received many helps from the staff of Liajia Coal Mine. In the process of writing articles, our friends give us a lot of advice. We are appreciated for that.

Conflicts of Interest: The authors declare no conflicts of interest. The founding sponsors had no role in the design of the study; in the collection, analyses, or interpretation of data; in the writing of the manuscript, and in the decision to publish the results.

\section{References}

1. Li, H.; Vink, J.C.; Alpak, F.O. An efficient multiscale method for the simulation of in-situ conversion processes. Soc. Pet. Eng. J. 2015, 20, 579-593. [CrossRef]

2. Zhang, L.; Liu, H.; Jia, C.; Qin, H.; Bai, J.; Sun, B.; Wang, Q.; Li, S.; Sun, J. Research progress of comprehensive utilization of oil shale in China. Chem. Ind. Eng. Prog. 2012, 11, 002.

3. Dyni, J.R. Geology and resources of some world oil-shale deposits. Oil Shale 2006, 20, 193-252.

4. Tong, J.; Jiang, X.; Han, X.; Wang, X. Evaluation of the macromolecular structure of Huadian oil shale kerogen using molecular modeling. Fuel 2016, 181, 330-339. [CrossRef]

5. Li, H.; Vink, J.C.; Alpak, F.O. A dual-grid method for the upscaling of solid-based thermal reactive flow, with application to the in-situ conversion process. Soc. Pet. Eng. J. 2016, 21, 2097-2111. [CrossRef]

6. Qian, J.; Yin, L. Oil Shale—Petroleum Alternative; China Petrochemical Press: Beijing, China, 2010; pp. 1-15.

7. Chen, M. Research on Characteristics and Fire Control Technology of Oil Shale in Haishiwan Coalfield. Master's Thesis, China University of Mining and Technology, Xuzhou, China, June 2014.

8. Mayne, C.L.; Solum, M.S.; Pugmire, R.J.; Fletcher, T.H. Oil shale pyrolysis rates and mechanisms. In Utah Oil Shale; CRC Press: Raton, FL, USA, 2016; pp. 153-190.

9. Zhang, Y.; Han, Z.; Wu, H.; Lai, D.; Glarborg, P.; Xu, G. Interactive matching between the temperature profile and secondary reactions of oil shale pyrolysis. Energy Fuels 2016, 30, 2865-2873. [CrossRef]

10. Bai, F.; Guo, W.; Lü, X.; Liu, Y.; Guo, M.; Li, Q.; Sun, Y. Kinetic study on the pyrolysis behavior of Huadian oil shale via non-isothermal thermogravimetric data. Fuel 2015, 146, 111-118. [CrossRef]

11. Lan, X.; Luo, W.; Song, Y.; Zhou, J.; Zhang, Q. Effect of the temperature on the characteristics of retorting products obtained by yaojie oil shale pyrolysis. Energy Fuels 2015, 29, 7800-7806. [CrossRef]

12. Loo, L.; Maaten, B.; Sirde, A.; Pihu, T.; Konist, A. Experimental analysis of the combustion characteristics of estonian oil shale in air and oxy-fuel atmospheres. Fuel Process. Technol. 2015, 134, 317-324. [CrossRef]

13. Ots, A. Formation of air-polluting compounds while burning oil shale. Oil Shale 1992, 9, 63-75.

14. Saif, T.; Lin, Q.; Butcher, A.R.; Bijeljic, B.; Blunt, M.J. Multi-scale multi-dimensional microstructure imaging of oil shale pyrolysis using $\mathrm{X}$-ray micro-tomography, automated ultra-high resolution sem, maps mineralogy and fib-sem. Appl. Energy 2017, 202, 628-647. [CrossRef]

15. Konist, A.; Valtsev, A.; Loo, L.; Pihu, T.; Liira, M.; Kirsimäe, K. Influence of oxy-fuel combustion of ca-rich oil shale fuel on carbonate stability and ash composition. Fuel 2015, 139, 671-677. [CrossRef]

16. Jiang, H.; Song, L.; Cheng, Z.; Chen, J.; Zhang, L.; Zhang, M.; Hu, M.; Li, J.; Li, J. Influence of pyrolysis condition and transition metal salt on the product yield and characterization via Huadian oil shale pyrolysis. J. Anal. Appl. Pyrolysis 2015, 112, 230-236. [CrossRef]

17. Wang, W. Research on Characteristics and Mechanism of Oil Shale Pyrolysis Reaction. Ph.D. Thesis, China University of Petrolrum (Beijing), Beijing, China, November 2016.

18. Aboulkas, A.; El Harfi, K. Study of the kinetics and mechanisms of thermal decomposition of moroccan tarfaya oil shale and its kerogen. Oil Shale 2008, 25, 426-443. [CrossRef]

19. Wang, D.-M.; Qi, X.; Zhong, X.; Gu, J. Test method for the propensity of coal to spontaneous combustion. Procedia Earth Planet. Sci. 2009, 1, 20-26. [CrossRef] 
20. Qin, B.; Dou, G.; Wang, Y.; Xin, H.; Ma, L.; Wang, D. A superabsorbent hydrogel-ascorbic acid composite inhibitor for the suppression of coal oxidation. Fuel 2017, 190, 129-135. [CrossRef]

21. Xie, Z.; Jin, L.; Ren, B. Characters of coal combustion and optimization of index gases. Saf. Coal Mines 2004, $35,10-12$.

22. Lu, P.; Liao, G.; Sun, J.; Li, P. Experimental research on index gas of the coal spontaneous at low-temperature stage. J. Loss Prev. Process Ind. 2004, 17, 243-247. [CrossRef]

23. Wang, G.; Yan, G.; Zhang, X.; Du, W.; Huang, Q.; Sun, L.; Zhang, X. Research and development of foamed gel for controlling the spontaneous combustion of coal in coal mine. J. Loss Prev. Process Ind. 2016, 44, 474-486. [CrossRef]

24. Wang, G.; Xie, J.; Xue, S.; Wang, H. Laboratory study on low-temperature coal spontaneous combustion in the air of reduced oxygen and low methane concentration. Tehničkivjesnik 2015, 22, 1319-1325.

25. Cheng, W.; Hu, X.; Xie, J.; Zhao, Y. An intelligent gel designed to control the spontaneous combustion of coal: Fire prevention and extinguishing properties. Fuel 2017, 210, 826-835. [CrossRef]

26. Ni, G.; Li, Z.; Xie, H. The mechanism and relief method of the coal seam water blocking effect (WBE) based on the surfactants. Powder Technol. 2018, 323, 60-68. [CrossRef]

27. Su, H.; Zhou, F.; Li, J.; Qi, H. Effects of oxygen supply on low-temperature oxidation of coal: A case study of Jurassic coal in Yima, China. Fuel 2017, 202, 446-454. [CrossRef]

28. Tang, Y. A laboratorial study of spontaneous combustion characteristics of the oil shale in Fushun, China. Combust. Sci. Technol. 2016, 188, 997-1010. [CrossRef]

29. Qi, G.; Wang, D.; Zheng, K.; Xu, J.; Qi, X.; Zhong, X. Kinetics characteristics of coal low-temperature oxidation in oxygen-depleted air. J. Loss Prev. Process Ind. 2015, 35, 224-231. [CrossRef]

30. Wang, H.; Dlugogorski, B.Z.; Kennedy, E.M. Thermal decomposition of solid oxygenated complexes formed by coal oxidation at low temperatures. Fuel 2002, 81, 1913-1923. [CrossRef]

31. Li, J.; Li, Z.; Yang, Y.; Wang, C. Study on oxidation and gas release of active sites after low-temperature pyrolysis of coal. Fuel 2018, 233, 237-246. [CrossRef]

32. Wang, G.; Liu, Q.; Sun, L.; Song, X.; Du, W.; Yan, D.; Wang, Y. Secondary spontaneous combustion characteristics of coal based on programed temperature experiments. J. Energy Resour. Technol. 2018, 140, 082204. [CrossRef] 